\title{
Margaret McCartney: Our politicians are wilfully failing the NHS
}

\author{
Margaret McCartney general practitioner
}

Glasgow

The NHS and, by logical extension, social care should be the defining touchstone of the 2017 general election. Whether or not there's a "humanitarian crisis," as the British Red Cross warned in January, ${ }^{1}$ the system is under unsustainable stress.

Under these circumstances, manifestos promising government that's "strong and stable" or "for the many not the few" must be backed up with hard evidence and thorough cost effectiveness calculations. After all, the surreal, persistent political misrepresentation of weekend mortality—all supposedly to justify a Conservative manifesto pledge from the last election-led to strikes and an overflowing, bitter cup for junior doctors.

Sadly, the 2017 manifestos seem no less damaging than the last Conservative one.

On spending, the Conservatives promise an increase for the NHS of "a minimum of $£ 8$ bn in real terms over the next five years." But this will be recycled money, not new. NHS funding was a central part of the Leave campaign's message in last year's referendum. The referendum was won with a pledge to "give our NHS the $£ 350 \mathrm{~m}$ the EU takes every week." Over five years that would equate to $£ 91 \mathrm{bn}$ of new money going to the NHS. Yet the Conservatives are now pledging only $£ 8$ bn of recycled money.

The Conservatives will also "review the operation of the internal market," citing bureaucracy and patients' interests. But why now? The internal market has failed in almost every aspect of its operation since it was introduced-but there's no admission that the internal market is neither evidence based nor cost effective. Is this new review being proposed simply to avoid NHS trusts going bankrupt? We don't know, because data on the financial situation of NHS trusts will probably not be available until after the election. ${ }^{2}$

It's also no surprise that the Conservatives want us GPs to give "greater access [to care] ... while ensuring care remains personal"-we're to be either cloned or sleepless. More sharing of GP data is pledged, without saying with whom and for what purpose. And they want more technology: phone and online consultations and "technology to triage people better." ${ }^{3}$ What of the evidence? We have pilots by private companies but no randomised controlled trials looking at harms.

The 2017 manifestos seem no less damaging than the last Conservative one

Labour politicians pledge $£ 30$ bn for the NHS over the next five years. ${ }^{4}$ They want to "halt and review" sustainability and transformation partnerships and repeal the Health and Social Care Act. They want a National Care Service, and they want to retain waiting time targets in emergency departments. But they don't mention safe staffing targets.

The Liberal Democrats offer £6bn to the NHS through adding a penny on tax. ${ }^{5}$ On mental health, they want to ensure that "the NHS is not picking up the tab for private malpractice." Bravo: this needs expanding to include all private screening services. The party contains science geeks, but they too want more Skype consultations despite limited evidence to date on benefits and harms. ${ }^{6}$

Health policy and manifesto pledges should be based on hard evidence and thorough cost effectiveness calculations. But I see no progress towards that goal in these manifestos. In the current political landscape the NHS is being wilfully failed and left to die on its knees.

\section{Competing interests: See www.bmj.com/about-bmj/freelance-} contributors/margaret-mccartney.

Provenance and peer review: Commissioned; not externally peer reviewed.

Follow Margaret on Twitter, @mgtmccartney

1 Campbell D, Morris S, Marsh S. NHS faces "humanitarian crisis" as demand rises, British Red Cross warns. Guardian 6 Jan 2017. https://www.theguardian.com/society/2017/jan/ 06/nhs-faces-humanitarian-crisis-rising-demand-british-red-cross.

2 Pym H. NHS Performance data delay "disappointing" regulator says. BBC News 19 May 2017. www.bbc.co.uk/news/health-39976701.

3 Conservative Party. Forward together: the Conservative manifesto. May 2017. https:// www.conservatives.com/manifesto.

4 Labour Party. For the many not the few. May 2017. www.labour.org.uk/page/-/Images/ manifesto-2017/labour-manifesto-2017.pdf.

5 Liberal Democrats. Our manifesto. May 2017. www.libdems.org.uk/manifesto. 
6 Greenhalgh T, Vijayaraghavan S, Wherton J, et al. Virtual online consultations: advantages and limitations (VOCAL) study. BMJ Open 2016;357:e009388. doi:10.1136/bmjopen2015-009388. pmid:26826147.
Published by the BMJ Publishing Group Limited. For permission to use (where not already granted under a licence) please go to http://group.bmj.com/group/rights-licensing/ permissions 